\title{
Chronic Prostatitis in Spinal Cord Injury Patients
}

\author{
J. J. Wyndaele, M.D. \\ Department of Urology (Professor W. A. De Sy) and S.C.I. Service (Professor Dr \\ $H$. Claessens), State University of Ghent, Belgium
}

\begin{abstract}
Summary
Six spinal cord injury patients with chronic prostatitis were reviewed, all of whom had been treated with an indwelling Foley catheter during the phase of spinal shock.

The 3 glass urine specimen test, the bladder wash-out test, a study of antibody coated bacteria and urethrography had limited diagnostic value. A specific diagnostic 5 glass specimen test proved to be useful and reliable.

Longterm antibiotic treatment was successful in only one patient. Injection of antibiotics into the prostate gland was ineffective in the five patients in whom it was carried out. During a follow up from 1 to 5 years urological complications were rare in all five patients who remained infected.
\end{abstract}

Key words: Paraplegia; Chronic prostatitis.

\section{Introduction}

Chronic bacterial prostatitis is known to be a cause of chronic urinary tract infection, and this also holds for spinal cord injury patients (Bedbrook, 1981; Cukier et al., 1976). The diagnosis of prostatitis is difficult, and the value of the different diagnostic procedures in patients with a neuropathic bladder is uncertain. The incidence of this infection in paraplegics is almost certainly underestimated (Juraschek, 1981).

We have reviewed a group of six paraplegics with proven chronic prostatitis.

\section{Methods}

In a group of 92 male paraplegics discharged from the Spinal Unit since 1979, 21 had a chronic urinary tract infection (U.T.I.). In 13 of these patients a cause for the chronicity could be found (Table 1).

In those patients with proven chronic prostatitis we reviewed the following data:

1. The tvpe of bladder drainage used during the phase of spinal shock and 
Table 1 Causes for the chronicity of the U.T.I. in 21 patients

\begin{tabular}{lc}
\hline & No. patients \\
\hline Chronic prostatitis & 6 \\
Infected calculi & 3 \\
High residual urine & 4 \\
Unknown & 8 \\
\hline
\end{tabular}

the results of the different diagnostic localising procedures performed in connection with the U.T.I.

2. The radiological investigation of the urethra.

3. The type of bacteria found in cultures of urine and of prostatic secretions.

4. The symptoms.

5. The outcome of treatment and the complications that occurred during follow up.

To localise the U.T.I., the following procedures were done, that is, a 3 glass urine specimen test (Meares, 1978) a bladder wash out test (Wyndaele et al. 1983); antibody coated bacteria test (Kwasnik et al. 1979).

We also performed a specific localisation test, Kuhlemeier et al. (1982).

\section{Description of the 5 glass specimen test}

A three-way indwelling balloon catheter charriere 18, was used. The smallest conduit (originally designed for the introduction of the rinsing liquid in the bladder), was filled at this end with silicone gel and a new opening was made in it distally from the balloon in order to communicate with the proximal urethra.

This catheter was introduced into the bladder. Through the unchanged conduit a urine sample was taken from the bladder (Sample 1). The balloon was then filled with $30 \mathrm{ml}$ of water. Throughout the test gentle traction was applied to the catheter in order to pull the balloon against the bladder neck. Ten $\mathrm{ml}$ of sterile saline was introduced through the small conduit and a first urethral wash out specimen was taken at the meatus (Sample 2).

Afterwards both bladder and urethra were rinsed with $150 \mathrm{ml}$ chloramine 3 per cent aqueous solution and then with $100 \mathrm{ml}$ sterile saline. After this a new bladder specimen and a new urethral wash out specimen were taken (Samples 3 and 4). Prostatic massage was then performed, and the expressed secretions were washed out of the urethra with another $10 \mathrm{ml}$ sterile saline and collected at the meatus (Sample 5). From all five samples a culture was carried out and the bacterial count determined. Typical results are shown in Table 2.

Table 2 Typical results of bacterial counts (organisms per $\mathrm{ml}$ ) in specimens collected with the 5 glass test

\begin{tabular}{lccccc}
\hline & $\begin{array}{c}\text { Bladder } \\
\text { specimen }\end{array}$ & $\begin{array}{c}\text { Urethral } \\
\text { specimen }\end{array}$ & $\begin{array}{c}\text { Bladder } \\
\text { wash out }\end{array}$ & $\begin{array}{c}\text { Urethral } \\
\text { wash out }\end{array}$ & $\begin{array}{c}\text { Prostatic } \\
\text { specimen }\end{array}$ \\
\hline Prostatitis & $>100.000$ & \pm 5000 & 0 & 0 & $>1000$ \\
No prostatitis & $>100.000$ & \pm 5000 & 0 & 0 & 0 \\
\hline
\end{tabular}


The conduit which remains open to the bladder gives the opportunity to check the sealing at the bladder neck, necessary to avoid spoiling of the urethral and prostatic samples by urine from the bladder. For the same reason the rinsing of the urethra and the bladder with chloramine solution tends to lower the risk of spoiling the prostatic sample.

We considered prostatitis as proved if at least 1000 bacteria per $\mathrm{ml}$ were found in the fifth (prostatic) sample together with a gross pyuria and if both bladder and urethral wash outs (Samples 3 and 4 ) were sterile.

As the prostatic secretions were diluted at least 10 times by the wash-out with $10 \mathrm{ml}$ sterile saline, a count of $>1000$ bacteria per $\mathrm{ml}$ should easily fall into the criteria proposed by Meares (1978) for the diagnosis of prostatitis.

\section{Results}

\section{Type of bladder drainage used}

All patients had been treated with an indwelling Foley catheter: three during the entire period of spinal shock, and three during a period of 2 weeks to 2 months post injury.

\section{3 glass urine specimen test}

In all patients, all three urine portions contained an equal amount of pyuria and an equal bacterial count on urine cultures ( $>100,000$ bacteria per $\mathrm{ml}$ ).

\section{Bladder wash out test}

A lower urinary tract infection was found in four patients and an upper urinary tract infection in two patients. In one of these, chronic pyelonephritis was known to be present.

\section{Antibody coated bacteria}

These were found in the urine samples of five of our patients. No search for antibody coated bacteria was performed on the prostatic secretions of the patients studied here.

\section{A 5 glass specimen test}

The results of this test demonstrated prostatitis in all patients. All prostatic secretions showed the same type of bacteria as were found on bladder urine and urethral cultures. Pyuria in the fifth sample greatly exceeded that which was found in the bladder and urethral samples. Wash outs of bladder and urethra after rinsing gave sterile cultures in all patients.

\section{Excretory and retrograde urethrography}

In two patients reflux of contrast material in the prostatic ducts was seen. One of these patients also showed prostatic calcifications shown by plain radiographs of the abdomen. 


\section{Bacteria}

Prostatitis was caused by Pseudomonas Áeruginosa in four patients and Proteus mirabilis in one patient, while different types of bacteria (including Pseudomonas) were found in the remaining patient.

\section{Symptoms}

As a result of their neurological lesions none of these patients had local specific symptoms. The prostate was not enlarged, nor did it feel pathological on palpation. In two patients several periods of urinary sepsis occurred during their stay in the spinal unit. All patients became catheter free. In four patients bladder re-education proved difficult. At discharge three had a small capacity bladder, which did not respond sufficiently to parasympathomimetic drugs, and their urinary incontinence obliged them to wear a condom catheter continuously. The other three patients achieved a satisfactory bladder balance and continence.

\section{Treatment}

General antibiotic treatment proved efficient in one patient and after 3 months of continuous treatment his urine and prostatic secretions became sterile and have remained so until now (follow up of 2 years). In five patients the U.T.I. persisted or reappeared after the antibiotics were stopped. Longterm and repeated general antibacterial treatment produced no therapeutic results in these five patients, but made the bacteria grow more and more resistant.

In five patients injection of 80 to $160 \mathrm{mg}$ Gentamycin directly into the prostatic tissue through a perineally introduced needle (once a day), on five consecutive days, had no lasting effect. In three of these patients urine cultures remained sterile for one week after the repeated injections, but the infection reappeared subsequently in all of them. No complications were seen from these injections.

Transurethral resection of the prostate carried out in one patient did not eliminate the chronic infection.

\section{Follow up}

In four patients who remained infected and in the one who was cured, no specific complications occurred during a follow up period from 1 to 5 years.

No alterations were found in their I.V.P. and in none did vesicoureteric reflux develop. One patient who remained infected had during a follow up of 5 years, two periods of symptomatic U.T.I. with high fever. In all three patients with an imbalanced bladder no improvement in urodynamic dysfunction was observed during the 1 to 2 years since their discharge.

\section{Discussion}

Chronic prostatitis is a notoriously difficult infection to eradicate and its prevention should have great attention by those in charge of acute spinal cord injury patients. All of the patients studied here had been treated with an indwelling 
Foley catheter for more than two weeks during the phase of spinal shock (Wyndaele et al., 1982). In another group of our patients who were treated with intermittent catheterisation no prostatitis occurred; clearly intermittent catheterisation would seem to be preferable to indwelling catheter drainage. Theoretically, bladder drainage with a fine bore cystostomy would also carry a low risk of prostatitis as it leaves the urethra open andhas a lowurinary tract infection rate(Namikiet al., 1978).

Prostatitis occurred in our patients early during re-education. These infections of the prostate gland were not caused by severe urethral sphincter spasticity or urethral strictures with an outflow obstruction of infected urine.

The diagnosis of prostatitis is not easy. As shown in our series the outcome of the 3 glass urine specimen test is uncertain in S.C.I. patients. They have incomplete control of micturition and the fact that infection is equally present in bladder, urethra and prostate makes differentiation and localisation practically impossible.

The bladder wash out test does not distinguish between a bladder and prostatic lower urinary tract infection. In patients with both prostatitis and pyelonephritis (as was present in one of our patients) the test will show evidence of an upper urinary tract infection.

It has been demonstrated that bacteria of prostatic origin can be antibody coated as occurred in five of our patients. But a good correlation with prostatitis was not found in a larger series (Kuhlemeier et al., 1982).

The 5 glass specimen test provides a new method diagnosing prostatitis in patients with a neuropathic bladder but more experience is needed to evaluate this test. With such experience in a larger series of patients we hope to be able to better define its indications, its practical application and its limitations.

The pathological signs of prostatitis on X-ray studies were found in only one third of our patients. Thus we cannot agree with other authors (Beurton-Herlant, 1983) that X-rays are the most important diagnostic tool in diagnosing prostatitis in patients with a neuropathic bladder. More specific diagnostic procedures should be performed more often in patients who remain infected despite the usual antibacterial treatment.

Although none of our patients had specific local symptoms, half were discharged from the S.C.I. centre with an inbalanced lower urinary tract, and it seems probable that the chronic urinary tract infection influenced this.

The treatment of chronic prostatitis in most cases is unrewarding. We had a cure in only one patient after 3 months of continuous antibiotic treatment. The lower urinary tract infection in this particular patient was caused by several different types of bacteria.

It is known that most antibiotics do not reach therapeutic concentrations in prostatic fluid (Stamey, 1972). We could cure our patient with longterm treatment using a combination of sulphamethoxazole and trimethoprim followed by treatment with doxycycline (Oosterlinck et al., 1976).

None of the antibiotics used today appear to be able to eradicate Pseudomonas prostatitis, and the infection in the majority of our patients was caused by this type of bacteria.

There were no good results from the injection of antibiotics into the prostate gland, contrary to what has been described by others (Baert, 1980).

Like Beurton and Herlant (1983) we have stopped all antibacterial medication 
in our patients who remained infected despite longterm antibiotic treatment. Follow up showed few complications till now but it seems justifiable to keep these patients under close control. Patients with chronic U.T.I. infection are known to carry a high risk of developing urological complications and to have a poorer prognosis for life expectancy (Bors and Comarr, 1971).

We hope that more specific antibiotics will be developed with good penetration into the prostate gland and with a specific activity against resistant bacteria in the infected prostate. Meanwhile, prevention holds the first place.

\section{Résumé}

Six patients paraplégiques, avec une prostatite chronique, ont été étudiés.

Tous avaient été traités avec une sonde à demeure pendant la période du shock spinal.

Le test à trois verres, le bladder wash out, la recherche de bactéries marquées d'anticorps et

l'uréthrographie se revelaient infiable. Seul un test specifique à 5 verres était utile et fiable.

Un seul patient fut guerri par antibiothérapie générale.

$\mathrm{L}$ ' injection d'antibiotiques dans la prostate n'eut aucun effet chez 5 patients. Ces 5 patients, qui restaient infectés n'avaient que peu de complications durant un follow-up de 1 à 5 ans.

\section{Zusammenfassung}

Bei 6 querschnitts-gelähmten Männern entwickelte sich eine chronische Prostatitis.

Sie waren alle, in der Spinalshockperiode mit einem Foley-Katheter behandelt worden. Der Dreigläsertest, der Blasenspültest, das Ansuchens von antibodycoated Bakterien und die Urethrographie erweisen sich als unzuverlässig. Nur ein Funfgläsertest erweis sich als nützlich und zuverlässig.

Es ergab sich, dass allgemeine antibiotische Behandlung nur bei 1 Patient zur Heilung führte. Injectionen mit Antibiotiken hatten keine wirkung bei 5 patienten.

Während eines Follow-up von 1 bis 5 Jahren sind fast keine Verwicklungen festgestellt worden bei allen 5 Patienten, die infiziert blieben.

\section{References}

BAert L 1980 Les prostatitis. Encycl. Méd. Chir. Rein, Paris 18520-A 10:10-1980.

BeDbrook G 1981 The Care and Management of Spinal Cord Injuries. Springer Verlag, New York.

Beurton D, Herlant M 1983 La prostatite chronique chez les paraplegiques. Considerations therapeutiques. Annales de Médicine Physique 25:425-431.

Bors E, COMARR AE 1971 Neurological Urology. S. Karger, Basel.

Cukier J, Maury M, Vacant J, MLle Lucet 1976 L'infection de l'appareil urinaire chez le paraplégique adulte. La Nouvelle Presse médicale 24:1531-1532.

JURASCHEK F 1981 Complications urétrales et leurs conséquences. In: Maury M (ed) La paraplégie. Flammarion Medicine-Sciences, Paris, ch 25:334-339.

KUHLEMEIER KV, LlOYd LK, STOVER SL 1982 Localisation of upper and lower urinary tract infections in patients with neurogenic bladders. SCI digest, Spring, p 336-342.

KWASNIK I, KLAUber G, Tilton RC 1979 Clinical and laboratory evaluations of antibody coated bacteria test in children. Journal of Urology 121:658-661.

MEARES EM 1978 Urinary tract infections in Men. In: Campbell's Urology. Vol. 1.

W.B. Saunders Company, Philadelphia, p 509-537.

NAMiki T, ITo H, YASUDA K 1978 Management of the urinary tact by suprapublic cystostomy kept under a closed and aseptic state in the acute stage of the patient with a spinal cord lesion. Journal of Urology 119:359-362.

OOSTERLINCK W, WALLIJN E, WYNDAELE JJ 1976 The concentration of doxycycline in human prostate gland and its role in the treatment of prostatitis. Scandinavian Journal of Infectious Diseases Supplement 9:85-88.

STAMEY TA 1972 Urinary Infections. Williams and Wilkins, Baltimore.

WyNDAELE JJ, De Sy WA, ClaEsSENS H 1982 Early urological complications in spinal cord injury patients treatment with a Foley catheter. Acta Urologica Belgica 50:335-342.

Wyndaele JJ, Oosterlinck W, De Sy WA, Claessens H 1983 The use of the bladder wash out test in patients with Spinal Cord lesions who have urinary tract infection. Paraplegia 21:294-300. 